\title{
Strategies to Mitigate COVID-19 Pandemic Impacts on Health and Safety of Workers in Construction Projects
}

\author{
Vinayak Kaushal ${ }^{*},{ }^{1}$ and Mohammad Najafi $^{2}$ \\ ${ }_{1,2}$ Center for Underground Infrastructure Research and Education (CUIRE), Department of Civil Engineering, The University of \\ Texas at Arlington, Box 19308, Arlington, TX, USA, 76019.
}

\section{Keywords}

COVID-19, Mitigation Strategies,

Health Impacts, Construction

Safety, Construction Workers,

Construction Projects.

\begin{abstract}
Coronavirus disease 2019 (COVID-19) is a respiratory illness caused by a virus called SARSCoV-2. With the global spread of COVID-19, there is a compelling need to improve the health and safety of workers employed in the construction projects (CP). Occupational characteristics, such as interfacing with the public and being in close quarters with other workers, not only put workers at high risk for disease, but also make them a nexus of disease transmission to the community. The objectives of this study are: (1) to evaluate the implications of COVID-19 pandemic on health and safety of workers in construction industry (CI), (2) to analyze the socio-economic-environmental impacts of the pandemic on construction, and (3) to recommend effective ten-point strategy to reduce COVID-19 impacts on the health of construction workers in CP. The required information is collected and analyzed based on the recently published literature, interviews, surveys, and industry experiences. The results reveal that hours of work, wages, workload and stress levels, access to paid leave, interactions with co-workers and supervisors, and health-promoting workplaces have major impacts on the well-being of workers, their families, and their communities. This study will be helpful for the owners, contractors, project managers and owners, and governmental authorities in adopting the effective strategies to improve the health and safety of workers as well as productivity and efficiency in construction projects.
\end{abstract}

\section{Introduction and Background}

Coronavirus disease 2019 (COVID-19) is a respiratory illness caused by a virus called SARS-CoV-2 [1]. As of January, 2021, worldwide, 91.5 million confirmed cases and 1.96 million confirmed deaths were reported by the WHO. The most distinguished feature of this pandemic is its rapid spread and a long incubation period [1].

Soon after months of the first COVID-19 cases, it had spread to more than 170 countries around the globe [1-2]. Due to the individual choices, appeals from the public, and regulatory requirements, e.g., stay-at-home or work-from-home, volumes of public travelling from one place to other declined rapidly throughout the world. People also started practicing social distancing as one of the preventive measures against this virus spread. For example, in the US with work-fromhome or stay-at-home orders, the average distance travel declined from $8.0 \mathrm{~km}$ to $1.6 \mathrm{~km}$ by March 2020 [2]. Individuals significantly cut back rather than maintaining a steady amount of traveling time [2-3] Transport operations which were dependent on the travel volumes for their revenue experienced significant declines and losses, including fare, fuel tax, and toll revenues. Workers working in transport companies like taxi drivers also faced a significant decline in their income and some even were fired from their jobs. In various industry sectors like e-commerce, the demand for transportation and logistics has also increased, which is not enough to cater the reduction in the conveyance demands of different sectors. Therefore, it takes a while to study and comprehend the complex nature of these decisions that affect the construction system [4-5].

\subsection{Past Pandemics}

In the past, there were epidemics like Ebola, dengue, and measles, that were disease pandemics and more confined. These diseases were more concentrated in a smaller number of countries or regions of the world [6]. With pandemics, challenges such as lack of knowledge, experience, and readiness arise. The entire globe is helpless to manage, contain, mitigate, respond to, and recover from these diseases. Characteristics of pandemic such as COVID-19 in terms of the origin, spread, lethality, contagion, treatment, containment, and recovery present substantial challenges for its management [7-8]. A vaccine has arrived in the US and other parts of the world like the UK and India, but in the past and even till date, other interventions such as isolation, quarantine, and social distancing are usually practiced.

\subsection{Nature of Pandemics}

Pandemics generally differ greatly from the natural hazards such as earthquakes, tsunamis, volcanoes, hurricanes, tornadoes, flooding, and wildfires, which have their adverse impacts on infrastructure and are also harmful to the humankind. Due to a pandemic like COVID-19, infrastructure such as buildings, roads, homes, vehicles, equipment and facilities are not affected. But these pandemics have adverse impact on human health and can cause them to fall sick, hospitalized, absent from work, and deaths. The infected people might not be able to completely recover from the disease and/or may take many months to get recovered [9]. Due to this, there is a direct/indirect impact on public-private agencies and government because of the increased health care costs and workers not being able to work, pay taxes, or conduct business. COVID-19 has largely impacted the cultural, educational, and social activities, in general. Typically, the pandemic has a long-lasting and devastating impact on the health and general human well-being [10-11].

\subsection{COVID-19}

COVID-19 led to a significant reduction in freight and passenger travel and resulted in increase in the air quality and reduction in the use of petroleum globally [12]. As COVID-19 primarily attacks the human respiratory system, people who live in the nearby areas 
having a poor air quality are greatly vulnerable to the pandemic [1113]. This relationship strengthens the concept that construction sectors have a major impact on environment and health of humans. It is easy to hypothesize that reduction in the release of emissions in the environment will reduce global warming and improve public health leading to a better ability to withstand any upcoming pandemic. Reduction of the negative environmental impacts from construction has been and will always continue to be an important and interesting research area in the time to come as well [10-15].

Since the past years, a great amount of research and efforts was done for making our construction system reliable, resilient and sustainable. The most significant forces behind these studies were natural occurring, such as floods, earthquakes, and hurricanes, which became natural disasters as our infrastructure was not designed for these calamities [12-14]. Most of this research was on comprehending and reinforcing the ties between construction system and other civil engineering lifelines such as power, communication, water- and wastewater systems. Unlike natural calamities and wars, COVID-19 did not impact the physical infrastructure systems. Rather, it directly affected the humans and related lives [14-18]. Undoubtedly, this pandemic has showed the importance of realizing and comprehending the importance of ties between the construction sector and end users. It is therefore clear that construction industry should be prepared for a larger variety of possible disruptions as compared to the past, and they must comprehend the different potential effects on these systems. Moreover, these types of pandemics increase the scope for the development of a reliable, resilient, and sustainable construction [14-20].

It has never happened in the history of construction industry (CI) that it had to accept the fact of worldwide threat to its workforce and changing public health regulations and constraints. It becomes interesting to investigate how CI workers seek to operate, maintain, and construct projects without risking the safety and health of construction stakeholders like workers, operators, engineers, fabricators, and project managers. The general public expects no disruptions in receiving important infrastructure services in these most tough times. Additionally, the public expects limited danger of virus spread due to the construction of CP. COVID-19 pandemic continues to have a significant impact on the workstyle of the CI. This pandemic also challenges and threatens the operations of CI that are facing an increasing effect of weather-related natural disasters. Therefore, investigation of the impacts of COVID-19 pandemic on health and safety of construction workers becomes utmost important Construction system is not only essential for the daily needs of human beings but also to mitigate the pandemic [1-10].

\section{Objectives}

The objectives of this study are: (1) to evaluate the implications of COVID-19 pandemic on health and safety of construction workers in $\mathrm{CP}$, (2) to analyze the socio-economic-environmental impacts of the pandemic on construction, and (3) to recommend effective ten-point strategy to reduce COVID-19 impacts on the health of construction workers in $\mathrm{CP}$. The required information is collected and analyzed based on the recently published literature, interviews, surveys, and industry experiences.

\section{Methodology}

Published papers were identified that directly or indirectly reported COVID-19 pandemic and its impacts on the health of construction workers in CP from past years through 2021. The required information is collected and analyzed based on the recently published literature from many databases such as Engineering Village, ProQuest, ASCE, and Google Scholar, and interviews, surveys, and industry experiences. This paper evaluates the implications of COVID-19 pandemic on health and safety of construction workers in $\mathrm{CP}$, analyzes the socio-economic-environmental impacts of the pandemic on construction, and recommends effective combatting strategies to reduce COVID-19 impacts on the health of construction workers in CP.

\section{Socio-Economic-Environmental Impact Analysis of COVID-} 19 Pandemic on Construction

For CI projects, key revenue sources include gas tax, sales taxes and user fees. According to the American Association of State Highway and Transportation Officials (AASHTO), these sources are at a risk, which projects about $30 \%$ decline in the revenue related to construction. At present, several agencies are in a difficult situation so far as their financial stability condition is concerned. This prevailing condition not only affects present capital and operations projects, but also their long-term sustainability and reliance [17-19].

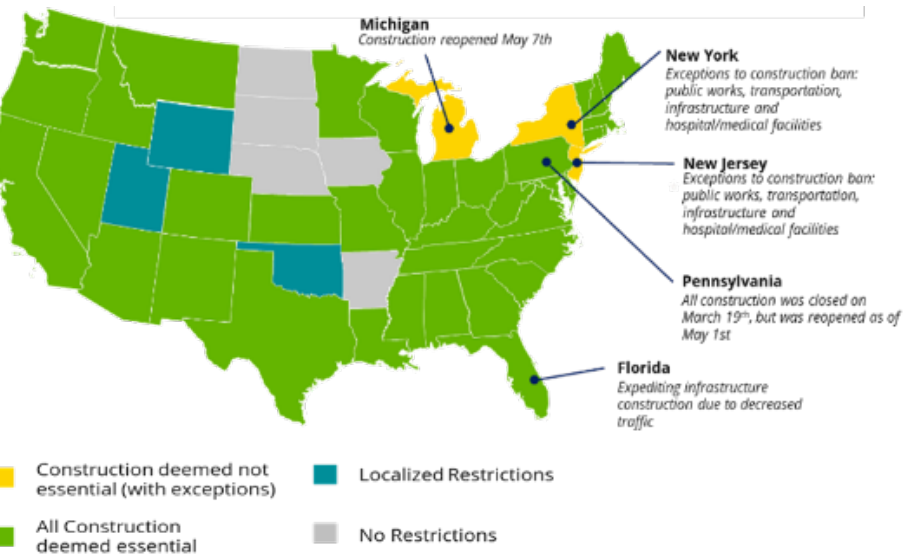

Therefore, there is a vital need for the state and federal transportation agencies to come up with suitable solutions, not only focusing on short-term relief but also steps that could lead to a long-term success. A detailed socio-economic-environmental analysis of COVID-19 pandemic on construction projects is discussed below.

\subsection{Construction Activity Disruption}

Almost all the economies are dependent upon the exchange and transportation of goods and services. CI is an essential component to facilitate the said exchange. CI workers construct the infrastructure and transport goods and services that help industry to survive and sustain, but the disruption of workforce that COVID-19 caused has been significant and substantial. For example, the CI in the US has more than 14 million workers and almost $10 \%$ of the country's workforce. Much of these construction workers contribute to the construction, operation, and maintenance of the public-private construction and to the nation's economy. About 10 billion transit trips by commuters have been recorded in 2019 with less earning populations being more reliant on construction for accessing their essential services in the US [17]. Figure 1 shows impacts of COVID-19 pandemic on the construction industry.

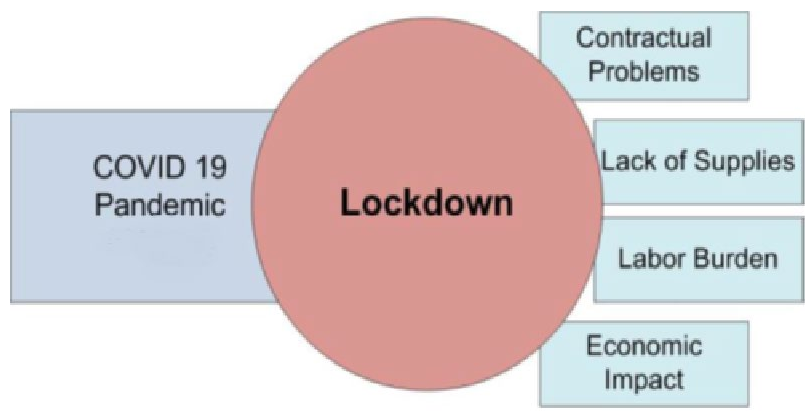

Figure 1. Impacts of the COVID 19 on Construction Industry [10]

Studies [17-19] show that COVID-19 impacts CI in two different ways: 
Direct Impacts: These include exposure to transit workers in frontline, decrease in transit service, cut in the wages for employees, and worktime loss or slow-down in construction due to social distancing [17]

Indirect Impacts: These include degradation of service for construction workers dependent upon travel for their employment, impacts on supply chain, e.g., reduction in sales of fuel, operation and maintenance services for equipment [17].

\subsection{Infrastructure Break off}

Since construction industry comes under essential sector, therefore, some projects are being carried out with additional precautions even during COVID-19 situation. At the same time, there are projects, which are delayed or are temporarily stopped due to shortage or cut in the budget. For example, in North Carolina, a tremendous decrease in the income has pushed the NC Department of Transportation below its required minimum capital limits. This department is not allowed to sign new contracts, and, had to postpone more than 100 projects amounting more than $\$ 2.2$ billion [17-19]. Figure 2 shows status of construction in different states of the US.

Figure 2. Status of construction in different states of the US [17]

There are other implications besides construction. As the construction workers and staff follow social distancing orders, a slowdown in the future project planning and design activities is also seen Moreover, inspections and maintenance issue in construction sector have also come to a halt, which was subject to delays due to shortage of staff.

For CP that follow new safety precautions to prevent COVID-19, it is most likely in that case for the lowering of construction productivity. Prevailing requirements of social distancing also limit the necessary physical contact for a lot of construction activities that results in reduction of worker efficiency. This ultimately has a negative impact on the schedule and budget of the CI project [17-19].

\subsection{Severe Impact on Taxes and Other Fees}

Like any other industry, the CI also is one of the major industries to bear the severe impact of COVID-19 outbreak and its related financial loss. There has been a drastic shift in the personal travel patterns with rapid changes in public health and safety guidelines and shelter-inplace orders issued by the local, state and federal authorities. Almost every metropolitan city has experienced a drastic decline in the traffic to as high as about $50 \%$ in some of the cities [17-19].

With the decrease in customer investment and the overall economic activity, the state and local transportation authorities have come under tremendous financial burden. Departments of transportation, which used to fund major capital projects related to highway and rail construction, are facing a decline in the revenues from conveyance and registration fees, and toll. In addition, transfers from genera funds are most likely to go down also. During the past economic depressions, sales taxes used to be a relatively stable source of revenue for the states, which does not appear to be happening today. The reason being that consumer investment is limited due to the social distancing guidelines by the governments and local agencies/authorities [17-19].

Having this drastic impact to the governments' tax revenues, their ability to meet their targets and other obligations is a matter of concern. At the same time, transportation agencies are majorly dependent on sales tax from locals and recoveries from fireboxes to subsidize system operations and maintenance. While there has been emergency support from the federal governments to cover operational losses, the next few months present a huge amount of financial challenge because these agencies continue to struggle to attract riders back onto the public conveyances. Additionally, the state transportation agencies have not received any support from the federal government that is believed to challenge their ability to operate and maintain the services during this pandemic time [20-23]
As per the AASHTO, a 30\% decline CP revenue has been projected nationwide CITE. However, there might be also some chances for transportation agencies to manage their finances and operations during this slow period. Figure 3 shows an overview of DOT and Transit Agency revenue sources.

\begin{tabular}{|c|c|c|c|}
\hline \multicolumn{2}{|c|}{$\begin{array}{c}\text { DOT Revenue } \\
\text { Stack* }\end{array}$} & \multicolumn{2}{|c|}{$\begin{array}{c}\text { Transit Operator Revenue } \\
\text { Stack }{ }^{\star}\end{array}$} \\
\hline = Rental Car Fee & $\begin{array}{l}5 \% \\
15 \%\end{array}$ & = Other (e.g. & $5 \%$ \\
\hline = Sales Tax & $5 \%$ & & \\
\hline $\begin{array}{l}\text { = Registration } \\
\text { Fees }\end{array}$ & $30 \%$ & $\begin{array}{l}\text { - Farebox } \\
\text { Revenues }\end{array}$ & $60 \%$ \\
\hline - Bond Proceeds & & $\begin{array}{l}\text { E State/Federal } \\
\text { Assistance }\end{array}$ & \\
\hline$=$ Gas Tax & $35 \%$ & & $15 \%$ \\
\hline $\begin{array}{l}\text { General Fund } \\
\text { Transfer }\end{array}$ & & Sales Tax & $13 \%$ \\
\hline
\end{tabular}

Figure 3. An overview of DOT and Transit Agency revenue sources [17]

This is also a good time for these agencies to prepare their organizations so as to adapt and become more resilient for the long run [17-26].

\subsection{Opportunity for Unique Projects}

During this COVID-19 times, critical CP require operations and maintenance as a virtue of essential services in different parts of the world. For example, around the US, the transportation agencies alone have a maintenance backlog of more than $\$ 98$ billion and the national highway system has a further backlog of $\$ 826$ billion for their operation and maintenance. Transportation agencies at the local, state and national levels are struggling due to a limited funds availability combined with a declining workforce due to social distancing regulations. Therefore, there is an opportunity for these agencies at different levels for addressing these critical needs, which result with the aging infrastructure, to improve the safety and health of the construction workers [26-28].

4.5

Socially Distanced Operations and Other Safety Measures

It is essential to run social distancing operations and other safety measures to safeguard the workers in CP. Public transportation systems are important both for rural and urban economies beginning the recovery from the COVID-19. As shelter in place restrictions begin to lift, the worker safety remains as the top priority. For example, the New York City Metropolitan Transportation Authority has put overnight service on hold to allow stations and trains time for disinfection. There is a potential to decrease risk by mandating an increased social distancing between workers, which would decrease capacity and require updated time schedules accounting for an increased loading time. Even when the social distancing regulations are removed, transit agencies may not see very many people (workers) using the transportation services for months or years [17-22].

Inspection and maintenance of $\mathrm{CP}$ should also ensure safety. Using innovative technologies, like drones, sensors, etc., can mitigate personal safety hazard for inspectors by enabling them to perform remote inspections or at least by maintaining a social distance. Remote inspections are highly encouraged for the benefit of transit agencies and the traveling public even when COVID-19 ends, and social distancing is not needed anymore [17-28]. 
Figure 4 shows three zones of risk in construction. The Safe Zone: where work can continue normally with no undue hazard present; the Hazard Zone: where workers are "working at the edge" (walking on thin ice); and the Loss of Control Zone: where accidents occur.

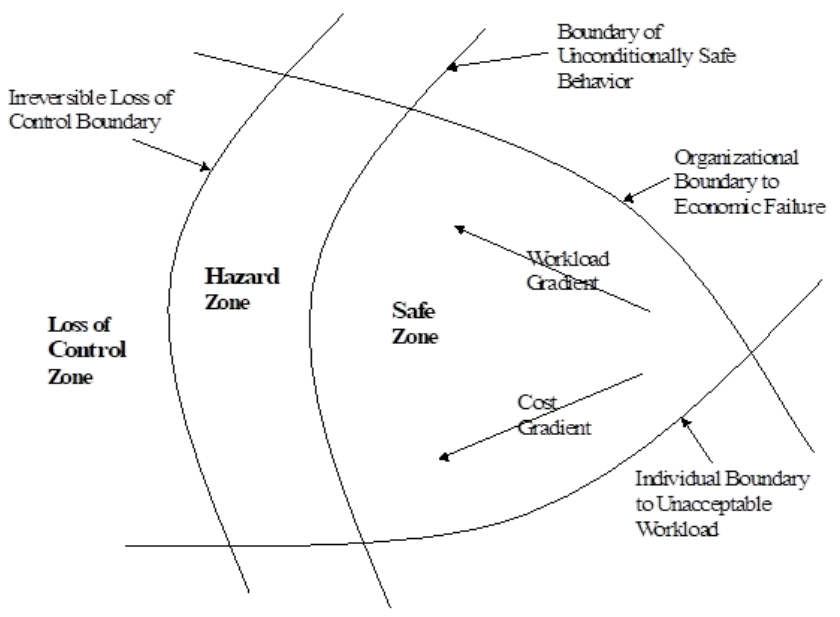

Figure 4. Three Work Zones of Risk in Construction [29]

It is believed that the boundary between the Safe Zone and the Hazard Zone should be identified to, and by, workers. Furthermore, author felt strongly that workers should be trained in ways to remain in the Safe Zone, ways to recover from the Hazard Zone back into the Safe Zone, and also how to identify, avoid, and ultimately recover from the Loss of Control Zone. According to the author, workload and economic pressures can push the worker from the Safe Zone toward the Hazard Zone, and eventually toward the Loss of Control Zone [29].

\subsection{Environmental Impacts of COVID-19 Pandemic}

There have been significant environmental impacts due to the COVID19 pandemic that indirectly have an influence on the health of workers. These impacts are classified to be as positive and negative, and are discussed as follows [28-32]

Positive Impacts. COVID-19 pandemic somehow showed positive impacts on the environment. Since people are working from home and do not need to travel to their offices, which reduced carbon dioxide emissions from the automobiles. Globally, most of the companies switched to online mode, due to which there is less carbon footprints from the stationary goods and services. Most of the meetings and events have started to be held remotely that has significantly decreased environmental emissions globally. Likewise, the lockdown in most of the countries has led to a substantial reduction in the greenhouse gas emissions. A reduction of more than $25 \%$ of carbon emission is reported in China. These impacts are directly related to construction industry as well [28-32].

There has also been reduction in the amounts of constituents in atmosphere such as black carbon (BC) and nitrogen dioxide (NO2) while a lower decrease occurs in particulate matter (PM10). On the other hand, a substantial increase in ozone (O3) concentration is reported. The reason for not showing a substantial increase in the PM10 as compared to other pollutants such as NO2 is due to the additives such as sea spray and desert powder, affecting countries like Italy, Greece, Spain, and the whole Mediterranean basin [32-34]. Therefore, more indepth investigation is needed due to the decline in PM10.

Negative Impacts. COVID-19 pandemic restricted the day-to-day mobility of people worldwide. This caused the factories, education, and training to close. Besides some major challenges in the international travel, it also impacted sports, entertainment, tourism, hospitality, manufacturing, transportation, and many other sectors. A damage of more than $\$ 100$ billion is expected to the global aviation industry due to such restrictions [39].
A study [40] was done to evaluate the impact of this pandemic at the global level on the supply chain, which directly or indirectly relates to the CI. The medical wastes coming out from the increased medical activity is one of the major concerns. During the pandemic peak in Wuhan, medical waste to the tune of 240 tons was produced daily in hospitals, which was a way more than the normal value [5]. In addition, medical masks made using plastic are another matter of concern and pose a serious threat to the environment. used worldwide are an environmental problem. There is no evidence yet for the transmission of the COVID-19 virus due to wastewater or sewage and healthcare waste. These impacts are also somehow indirectly related to the health of construction workers [40-50].

\section{Ten-Point Strategy to Combat Impacts of COVID-19 Pandemic in Construction Projects}

Based on the literature and findings, COVID-19 is seen to be a global pandemic that requires an effective combating strategy. To mitigate the impacts of COVID-19 pandemic on the construction workers in CP, the ten-point strategy is recommended and discussed as follows:

\subsection{Social Distancing}

The concept of distancing socially has turned out to be one of the most effective measures to prevent the transmission of COVID-19. Different health organizations recommend keeping a separation of at least one meter from other persons to mitigate the risk of COVID-19 transmission. Similar approach is required to be implemented among the construction workers in CP. As per the literature and current practice, it is a general advise to keep a distance of 1.0, 1.5, or 2.0 meters between one another in the outdoor environments, but for indoor environments where a larger distance is recommended [50-52].

\subsection{Use of Face Masks}

The use of face masks to contain the virus for construction workers in $\mathrm{CP}$ has been in arguments initially. Arguments suggest the effectiveness about their efficiency, absence of proper information on how to properly wear the masks, and the potential possibility of using risk behaviors while wearing masks. In the beginning, the WHO recommended the use of face masks just for the ones showing respiratory symptoms and for workers in healthcare services. However, later the use of fabric masks was acceptable and made mandatory in public [52]

The latest research suggests the use of universal mask as critical to contain COVID-19 spread. Face masks could substantially mitigate the number of pathogenic viruses in exhaled breath. The filtration capability of fabric masks was found to be more than $80 \%$ for particles less than $300 \mathrm{~nm}$ and more than $90 \%$ for particles less than $300 \mathrm{~nm}$ size. Therefore, use of face mask by construction workers in CP could be a very effective way of mitigating transmission of COVID-19 pandemic [52]

\subsection{Personal Cleanliness, Sanitization, and Ventilation}

Literature suggests that COVID-19 virus remains harmful starting from hours to few days depending upon the surface types. Cleaning of frequently touched equipment surfaces on a construction site would be helpful. Sanitization of equipment and construction sites depending on the need and resources is an essential measure to be adopted [52]

Thorough evaluations on the effectiveness of preventive measures by the construction workers involved in $\mathrm{CP}$ are needed. It is also important for construction workers to use the personal protection equipment and hygiene measures. Every required information needs to be quickly spread among the workers, including contact and cleanliness standards, the right use of masks, and be careful if another worker demonstrates fever and coughing symptoms.

The available literature and limited evidence suggest that air conditioning may contribute in spreading the virus in indoor 
environments. Therefore, it will be helpful to use air ventilation and conditioning systems on a non-recirculation mode [52-54].

\subsection{Social Equity}

As working from home is not very realistic for construction workers in $\mathrm{CP}$, they are more vulnerable to the attack of COVID-19. In this connection, the motive of public transportation and infrastructure sector authorities as a propagator of social collaboration rather than of social segregation seems less often today than ever before. Due to the COVID-19 outbreak, construction work never really came to a halt because of its consideration as an essential sector [52-54].

\subsection{Sustainable Design and Construction of Projects}

A steep decrease in the demand of public transportation because of the new social distancing and the risk of COVID-19 spread cause many concerns for the resilience of design and construction of CP in cities. With this regard, the construction workers involved in the $\mathrm{CP}$ need to be taken care of by the government and other private transportation agencies so far as their employment is concerned. Design and construction of a sustainable $\mathrm{CP}$ that are likely to be prolonged needs many cooperative efforts from public transportation agencies, policy makers, workers, and end-users. The objective must be to make sure that public transportation is as safe as possible and that it is able to accommodate and attract as much as people than those who have no reliable options [54].

\subsection{Adequate Planning of Infrastructural Facilities}

Construction workers in CP sharing the same equipment and facilities are especially susceptible to virus transmission if proper precautions not taken. This is valid for construction projects having many workers with diverse origins and destinations. Being and working together in such an environment is a potential health concern. Therefore, adequate planning of infrastructural facilities to make sure the health of construction workers and indirectly, their families at home is safe [54].

\subsection{System Robustness Against COVID-19}

The services offered by construction workers in $\mathrm{CP}$ is not solely ideal and serves as a catalyst for the transportation of goods and services, but also a potential catalyst for adversity, such as COVID. Robustness of any given system is measured as its capacity to withstand jolt and again come back to normal. Therefore, there is a need of a robust plan for construction workers in $\mathrm{CP}$ to fight against the prevailing pandemic conditions [54].

\subsection{Devising Mitigation Measures in Construction Projects}

Public construction projects are important in the economy of any nation. Therefore, it becomes essential to devise virus mitigation measures for the construction workers to maintain the essence as an important infrastructure as much as possible. The investigation of the CP's robustness and resilience has mostly been limited to supply performance, accessibility and connectivity for the end-user [53-54].

\subsection{Virus Quantification}

Comprehending and quantifying the virus spread in construction workers in $\mathrm{CP}$ is of utmost importance for assessing their health consequences. Devising transportation and epidemiological models to analyze the contact statistics and resulting consequences would be a great aid. The contact statistics reflect how many workers potentially encounter pandemic during a construction project. This model will also assign construction project need for the service network and this output will be used as an input for the pandemic spreadsheet model that will help update the status of virus carriage [55-58].

\subsection{Medical Technological Development}

Medical technological developments such as testing more construction workers who get affected or are susceptible to the virus and faster treatment will help significantly reduce the impact of pandemic in CP. Contact tracing is another effective way out that can prove to be helpful. Public health agencies worldwide are working on to developing and bringing out such applications [58-62].

\section{Conclusions}

This paper evaluated the implications of COVID-19 pandemic on health and safety of construction workers in $\mathrm{CP}$, analyzed the socioeconomic impacts of the pandemic on CI, and recommended effective ten-point strategy to reduce COVID-19 impacts on construction workers in construction industry. It can be concluded that it is essential to take care of workers' health and safety in the construction industry being prone to pandemic. Given the important role that workers in construction industry play in the economy of any country, it is essential that the government and non-governmental organizations devise an effective way outs to better maintain their health.

During the natural disasters, the workers working in construction projects help the general public in affected areas and allow the most affected parties to have the access to these areas on priority basis. A strategic plan to protect the public transportation operators/workers and other conveyance systems should be increased and restructured to facilitate a better social distancing. In addition, the workers working in freight transportation and logistics systems that aid to maintain important lifelines such as food, water, power and communications at the time of pandemic require special attention and a sustainable addressable policy.

Results and analysis based on the previous studies also show that globally, COVID-19 impacted the social and environmental wellbeing of humankind. Literature suggests a significant relationship between the environment and renewable energy sectors due to this pandemic. The pandemic caused enormous environmental waste due to the medical supplies and goods and led to a decline in household waste from people who were staying at home and concerned about sociological concerns. Significant decrease in greenhouse gas emissions were also observed due to the decline in the usage of road travel, industrial, educational and other activities, which also indirectly affects the health of construction workers.

\section{Limitation of this Study}

Due to the unavailability of actual data on COVID-19 from the construction site and limited specific literature on this subject, this study lacks quantitative analysis. The authors are however developing this research to further make it more data oriented, and also to do some comparative analysis.

\section{Recommendations for Future Research}

For further research, it is recommended to have a thorough and comprehensive data for proper planning and decision-making, and improvising the impacts of COVID-19 on the health of construction workers in $\mathrm{CP}$. It is also important to adequately understand the associated risk and critically perform a risk tolerance and management for effectiveness of analysis. New safety frameworks and procedures are needed to be implemented for the success of combating COVID-19 pandemic. There is a need to further increase the multidisciplinary research between $\mathrm{CI}$ and public health researchers. There is also a need to identify the near-future issues that arise from the financial impacts of COVID-19 and to develop a program to prioritize and fund $\mathrm{CP}$.

There is a need to collect and analyze information about COVID-19 from daily updates, internal operations memos, and public news for further investigation. The impacts will include major pandemic issues, such as essential versus non-essential operations, construction site shutdown (planned or unplanned), project suspension at any stage of construction (for a designate or unknown 
period of time), restarting construction, project continuation, suspension, and delay, expedited construction operations to take advantage of the declined traffic and receive early completion incentives, and occupational safety policies (social distancing and wearing N95 masks). Successful identification of the factors impacting decision-making processes will be critical for the develop of a novel multi-attribute utility choice models that capture the risk preferences of decision makers in the construction industry under pandemic uncertainties. In addition, a healthy coordination and connection between the public-private entities and identification of the opportunities for a sustainable asset management would be an effective step in this direction. Further research is also needed to evaluate and adopt new cost-effective technologies that enhance the health and safety construction workers in $\mathrm{CP}$.

\section{Declaration of Conflict of Interests}

The authors declare that there is no conflict of interest. They have no known competing financial interests or personal relationships that could have appeared to influence the work reported in this paper.

\section{References}

[1.] Hendrickson, C., \& Rilett, L. R. The COVID-19 Pandemic and Transportation Engineering. J. Transp. Eng. (2020).

[2.] McLeod, J. COVID-19: Retailers scrambling to respond to a surge in e-commerce orders during pandemic. (2020). Accessed April 10, 2020. https://business.financialpost.com/news/retailmarketing/covid-19-retailers-e-commerce-surge.

[3.] MTI (Maryland Transportation Institute), Center for Advanced Transportation Technology Laboratory, and Univ. of Maryland. COVID-19 impact analysis platform. (2020). Accessed September 12, 2020. https://data.covid.umd.edu/.

[4.] Arezki, R. and Nguyen, H. Novel coronavirus hurts the Middle East and North Africa through many channels. In Baldwin, R. and di Mauro, B.W. (eds). Economics in the Time of COVID-19. (2020). A VoxEU.org Book, Centre for Economic Policy Research, London. Accessed 26 September 2020 at: https://voxeu.org/system/files/epublication/CovID-19.pdf

[5.] Baldwin, R. and di Mauro, B.W. Economics in the Time of COVID19. A VoxEU.org Book, Centre for Economic Policy Research, London. (2020). Accessed 26 March 2020 at: https://voxeu.org/system/files/epublication/COVID-19.pdf

[6.] Beck, T. Finance in the times of coronavirus. In Baldwin, R. and di Mauro, B.W. (eds). Economics in the Time of COVID-19. A VoxEU.org Book, Centre for Economic Policy Research, London. (2020). Accessed 26 March 2020 at: https://voxeu.org/system/files/epublication/COVID-19.pdf

[7.] Biron, B., and Zhu, Y. Major fast-food chains and retailers in China are shutting their doors as the deadly coronavirus continues to spread. Here's a list of closures. Business Insider. (2020). Accessed 31 March 2020, from https://www.businessinsider.com/coronavirus-fearsmcdonalds-starbucks-close-2020-1

[8.] Bloomberg. China's Inflation Slows as Coronavirus Locks Down Economy. Bloomberg News. (2020). Accessed March 21 at: https://www.bloomberg.com/news/articles/2020-03-10/chineseinflation-slows-in-february-factory-deflation-returns.
[9.] Boone, L. OECD Economic Outlook. Organisation for Economic Cooperation and Development. (2020). Accessed 25 March 2020 from https://www.oecd.org/economic-outlook/

[10.] Al Amri, T., and Marey-Pérez, M. Impact of Covid-19 on Oman's Construction Industry. Technium Soc. Sci. J. (2020). 9, 661.

[11.] Boone, L. Tackling the fallout from COVID-19. In Baldwin, R. and di Mauro, B.W. Economics in the Time of COVID-19. A VoxEU.org Book, Centre for Economic Policy Research, London. (2020). $\begin{array}{llll}\text { Accessed } & 26 & \text { March } & 2020\end{array}$ https://voxeu.org/system/files/epublication/COVID-19.pdf.

[12.] Bullion, V. Gold Price Chart, Live Spot Gold Rates, Gold Price Per Ounce/Gram | BullionVault. (2020). Accessed 26 March 2020, from https://www.bullionvault.com/gold-price-chart.do.

[13.] Centers for Disease Control and Prevention. Pandemic influenza plan: 2017 update. (2020). Accessed September 20, 2020. https://www.cdc.gov/flu/pandemic-resources/pdf/pan-flureport-2017v2.pdf.

[14.] Parr, S., Wolshon, B., Renne, J., Murray-Tuite, P., \& Kim, K. Traffic Impacts of the COVID-19 Pandemic: Statewide Analysis of Social Separation and Activity Restriction. Natural Hazards Review. (2020). 21(3), 04020025.

[15.] Eroğlu, H. Effects of Covid-19 pandemic on environment and renewable energy sector. Environment, Development and Sustainability, 1-9. (2020).

[16.] Abdelhamid T., Patel B., Howell G. A. and Mitropoulos P. Signal Detection Theory: Enabling work near the Edge. Proceedings of the 11th Conference of the International Group of Lean Construction. (2003). Virginia Tech, Blacksburg.

[17.] Falk, A, Tucker, J., Hewlett, C., Zubin, P., Villalbi, V. Transportation Infrastructure and COVID-19. (2020). Delloite, 2020.

[18.] Verma, A., \& Prakash, S. Impact of covid-19 on environment and society. Journal of Global Biosciences, 9(5), 7352-7363. (2020).

[19.] Abdelhamid, T. and Everett. Identifying Root Causes of Construction Accidents. Journal of Construction Engineering and Management. (2020). ASCE, 52-59.

[20.] Bandyopadhyay, S. Coronavirus disease 2019 (COVID-19): We shall overcome. Clean Technologies and Environmental Policy, 22(3), 545-546. (2020). https://doi.org/10.1007/s10098-02001843-w

[21.] Bianca, M., Sally, H., \& Claire, M. The impact of the coronavirus on the renewable energy industry-Center for American Progress. Centre for American Progress. (2020). Retrieve April 21, 2020, from https://www.americanprogress.org/issues/green /news/2020/04/15/48321 9/impact-coronavirusrenewableenergy-industry/

[22.] Birol, F. Put clean energy at the heart of stimulus plans to counter the coronavirus crisis-Analysis-IEA (pp. 1-4). IEA. (2020). Retrieved April 21, 2020, from https://www.iea.org/commentaries/put-clean-energy-at-theheart-of-stimulus-plans-to-counter-the-coronavirus-crisis.

[23.] Broberg, E. Risk Estimation for Common Consumer Products. Proceedings of the Human Factors Society 30th Annual Meeting. Santa Monica, CA: Human Factors Society. (2020). pp. 556-560

[24.] Brown, I. Accident Reporting and Analysis. In J. Wilson and E Corlett (eds.), Evaluation of Human Work. London: Taylor \& Francis. (2020). pp 755-778.

[25.] Bureau of Labor Statistics. Career Guide to Industries, U.S Department of Labor, 2004-2005 Edition. (2020). http://www.bls.gov/oco/cg/cgsoo3.htm (Sept 19, 2005).

[26.] CDP. The relationship between climate change and coronavirus (Covid-19). CDP Turkey. (2020). Retrieved April 20, 2020, from https://cdpturkey.sabanciuniv.edu/tr/content/iklimcoronavirus. 
[27.] Cellar, D.F., Nelson, Z.C., Yorke, C.M., and Bauer, C. The Five Factor Model and Safety in the Workplace: Investigating the Relationships Between Personality and Accident Involvement. Journal of Prevention and Intervention in the Community. The Hayworth Press, Inc. (2020). Vol. 22, No. 1, p. 43-52.

[28.] Chua, D.K.H., and Goh, Y.M. Incident Causation Model for Improving Feedback and Safety Knowledge. Journal of Construction Engineering and Management. ASCE. (2004). pp. 542-551.

[29.] Bernuth, S. The Relationship Between Construction Worker Safety Awareness And Personality. Thesis submitted to Michigan State University, MI. (2006).

[30.] Cochran, J.H. Coronavirus monetary policy. In Baldwin, R. and d Mauro, B.W. (eds). Economics in the Time of COVID-19. A VoxEU.org Book, Centre for Economic Policy Research, London. (2020). Accessed 26 March 2020 at: https://voxeu.org/system/files/epublication/COVID-19.pdf

[31.] Cohen, J., \& Kupferschmidt, K. Strategies shift as coronavirus pandemic looms. Science, (6481), 962-963. (2020). Accessed from https://science.sciencemag.org/content/367/6481/962

[32.] Conte, M., Merico, E., Cesari, D., Dinoi, A., Grasso, F. M., Donateo, A. Long-term characterization of African dust advection in southeastern Italy: Influence on fine and coarse particle concentrations, size distributions, and carbon content. Atmospheric Research. https://doi.org/10.1016/j.atmosres.2019.104690

[33.] Conticini, E., Frediani, B., \& Caro, D. Can atmospheric pollution be considered a co-factor in extremely high level of SARS-CoV-2 lethality in Northern Italy? Environmental Pollution. (2020). https://doi.org/10.1016/j.envpol.2020.114465

[34.] Contini, D., \& Costabile, F. Does air pollution influence COVID-19 outbreaks? Atmosphere, 11(4), $377 . \quad$ (2020). https://doi.org/10.3390/atmos11040377

[35.] Coppel, K., \& Liu, A. New Frontier: The 2018 Report. Knight Frank Research. (2020). Accessed from https://content.knightfrank.com/research/1438/documents/en/ new-frontiers-the-2018-report-2018-5216.pdf

[36.] Cornwell, S., Morgan, D., and Shepardson, D. What's in the nearly $\$ 2$ trillion U.S. Senate coronavirus stimulus? World Economic Forum. (2020). Accessed 27 March 2020 at: https://www.weforum.org/agenda/2020/03/senate-coronavirusstimulus-covid19-united-states-health-economics/

[37.] Craik, C.H., Hogan, R., and Wolfe, R.N. Fifty Years of Personality Psychology, Plenum Press, New York, NY. (1993).

[38.] Megahed, N. A., \& Ghoneim, E. M. Antivirus-built environment: Lessons learned from Covid-19 pandemic. Sustainable Cities and Society. (2020). 61, 102350.

[39.] Shen, Y., C. Li, H. Dong, Z. Wang, L. Martinez, Z. Sun, A. Handel. Airborne transmission of COVID-19: epidemiologic evidence from two outbreak investigations. (2020). Preprint available at: https://www.researchgate.net/publication/340418430_Airborne _transmission_of_COVID19_epidemiologic_evidence_from_tw o_outbreak_investigations.

[40.] Sverigesradio. The government provides money so that public transport can run as usual. (2020). https://sverigesradio.se/sida/artikel.aspx?programid=4916\&arti kel $=7470922$

[41.] Tanguay, G. A., and U. Lachapelle. Remote work worsens inequality by mostly helping high-income earners. The Conversation. (2020). https://theconversation.com/remote-workworsens-inequality-by-mostly-helping-high-income-earners136160

[42.] Terrill, M. Shame about the cars, but Premier is right to be cautious about public transport. Sydney Morning Herald, (2020). https://www.smh.com.au/politics/nsw/shame-about-the-carsbut-premier-is-right-to-be-cautious-about-public-transport20200518-p54txr.html.

[43.] The Economist. Covid-19 threatens Europe's success at fighting inequality. (2020). Accessed June 9, 2020. https://www.economist.com/europe/2020/06/06/covid-19threatens-europes-success-at-fighting-inequality.

[44.] Henson, T., and M. Timmons. Public transit emergency preparedness against Ebola and other infectious diseases: Legal issues. Legal Research Digest 50. (2020). Washington, DC: Transportation Research Board.

[45.] Houston, N. Using highways during evacuation operations for events with advance notice: Routes to effective evacuation planning primer series. (2020). Accessed May 20, 2020. https://ops.fhwa.dot.gov/publications/evac_primer/primer.pdf.

[46.] Houston, N., A. Vann Easton, E. A. Davis, J. Mincin, B. D. Phillips, and M. Leckner. Evacuating populations with special needs. Routes to effective evacuation planning primer series. Washington, DC: USDOT. (2020).

[47.] Houston, N., J. Wiegmann, R. Marshall, R. Kandarpa, J. Korsak, C. Baldwin, and A. Vann Easton. Information-sharing guidebook for transportation management centers, emergency operations centers, and fusion centers. (2020). Accessed May 20, 2020. https://ops.fhwa.dot.gov/publications/fhwahop09003/tmc_eoc_ guidebook.pdf.

[48.] Kilbourne, E. Influenza pandemics of the 20th century. Emerging

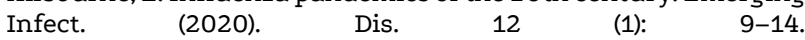
https://doi.org/10.3201/eid1201.051254.

[49.] Kim, K., O. Francis, and E. Yamashita. Learning to build resilience into transportation systems. Transp. Res. Rec. (2020). 2672 (1): 30-42. https:// doi.org/10.1177/0361198118786622.

[50.] Kim, K., P. Pant, and E. Yamashita. Integrating travel demand modeling and flood hazard risk assessment for evacuation and sheltering. Int. J. Disaster Risk Reduct. (2020). 1177-1186. https://doi.org/10.1016/j.ijdrr.2017.10.025.

[51.] Kim, K., P. Pant, E. Yamashita, and J. Ghimire. Analysis of transportation disruptions from recent flooding and volcanic disasters in Hawaii. Transp. Res. Rec. (2020). 2673 (1): 194-208. https://doi.org/10.1177/0361198118825460.

[52.] DeBord, M. General Motors and Ford are ramping up ventilator production to fight the coronavirus pandemic. Here's where they are now. Business Insider. (2020). Accessed 31 March 2020, from https://www.businessinsider.com/coronavirus-general-motorsford-ventilator-production-progress-2020-3.

[53.] DeCambre, M. The Dow is on pace for its worst month since the Great Depression, but here's why all hope isn't lost amid the coronavirus crisis. Market Watch. (2020). Accessed 31 March 2020, from https://www.marketwatch.com/story/the-dow-is-onpace-for-its-worst-month-since-the-great-depression-butheres-why-all-hope-isnt-lost-amid-the-coronavirus-stockrout-2020-03-21.

[54.] Tirachini, A. South America: The challenge of transition. In A Research Agenda for Transport Policy, edited by J. Stanley and D. Hensher, 118-25. Edward Elgar Publishing. (2020). https://doi.org/10.4337/9781788970204.00023.

[55.] Kaushal, C.P. and Kaushal, V. Impact of COVID-19 on Higher Education in India: Lessons Learned and Mitigation Measures, Journal of Nature, Science \& Technology, 1(2021), 10-13.

[56.] Tirachini, A., C. E. Cortés, and S. R. Jara-Díaz. Optimal design and benefits of a short turning strategy for a bus corridor. Transportation. (2020). 38: 169-89. https://doi.org/10.1007/s11116-010-9287-8.

[57.] Tirachini, Alejandro \& Cats, Oded. COVID-19 and Public Transportation: Current Assessment, Prospects, and Research 
Needs. Journal of Public Transportation, 22 (1). (2020). DOI: https://doi.org/10.5038/2375-0901.22.1.1

[58.] DiMauro, B.W. Macroeconomics of the flu. In Baldwin, R. and di Mauro, B.W. (eds). Economics in the Time of COVID-19. A VoxEU.org Book, Centre for Economic Policy Research, London. (2020). Accessed 26 March 2020 at: https://voxeu.org/system/files/epublication/COVID-19.pdf

[59.] DW. Coronavirus and the economy: World 'clearly' in recession, IMF says. Deutsche Welle. (2020). Accessed 29 March 2020 at: https://www.dw.com/en/coronavirus-and-the-economy-worldclearly-in-recession-imf-says/a-52943601

\section{How to Cite This Article}

Kaushal, V. and Najafi, M. Strategies to Mitigate COVID-19 Pandemic Impacts on Health and Safety of Workers in Construction Projects, Civil Engineering Beyond Limits, 2(2021) https://doi.org/10.36937/cebel.2021.002.001
[60.] Brown R, Scholl J. Idaho governor extends stay-home order through April 30 because of coronavirus. (2020). Available online at:

https://www.idahostatesman.com/news/coronavirus/article242 012651.html (2020, April 15).

[61.] CDC. Coronavirus Disease 2019 (COVID-19). (2020). Available online at: https://www.cdc.gov/coronavirus/2019-ncov/casesupdates/cases-in-us.html

[62.] Quinn SC, Kumar S. Health inequalities and infectious disease epidemics: a challenge for global health security. Biosecur Bioterror. (2014) 12:263-73. 